Part of Journal of Research of the National Bureau of Standards, Volume 24, January 1940

\title{
COLORIMETRIC DETERMINATION OF ARSENIC IN FERROUS AND NONFERROUS ALLOYS ${ }^{1}$
}

\author{
By Clement J. Rodden
}

\section{ABSTRACT}

A method is described for the determination of arsenic and has been applied successfully to iron, steel, copper-base alloys, tin- and lead-base bearing metals, and pig lead. The arsenic is first separated from the other constituents of the material by distillation as the trichloride. It is then oxidized to arsenic acid and converted to a blue arsenic-molybdenum compound by treatment with a solution containing hydrazine sulfate and ammonium molybdate. The transmittancy of the colored solution is measured with a photoelectric colorimeter, and the amount of arsenic read from a curve obtained by using known amounts of arsenic. Alternatively, the color may be matched against standards by means of a visual colorimeter. The method is reasonably rapid and is applicable to amounts of arsenic as small as 2 micrograms.

\section{CONTENTS}

I. Introduction

II. Apparatus_....... 8

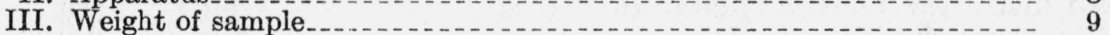

IV. Procedure

V. Results $\ldots$

\section{INTRODUCTION}

Arsenic in ferrous and nonferrous alloys is usually separated from other elements by distilling it as arsenic trichloride and is then determined by (a) weighing as the sulfide, (b) converting the arsenious sulfide to silver arsenate and titrating the silver with potassium thiocyanate, or (c) neutralizing the hydrochloric acid in the distillate and titrating with iodine or potassium bromate. ${ }^{2}$ Other methods have been used, especially for white metals; for example, arsenic is sometimes separated as the element from a hydrochloric-acid solution of the metal or alloy by reduction with sodium hypophosphite, ${ }^{3}$ stannous chloride ${ }^{4}$ or calcium hypophosphite. ${ }^{5}$ The arsenic thus obtained is dissolved in an excess of standard iodine solution and the excess iodine titrated with standard sodium arsenite solution. Alternatively, the arsenic may be converted to arsenious acid and titrated with bromate. $^{6}$

1 Presented before the Division of Microchemistry at the 98th Meeting of the American Chemical Society, Boston, Mass., September 11 to 15, 1939.

2 G. E. F. Lundell, J. I. Hoffman, and H. A. Bright, Chemical Analysis of Iron and Steel (John Wiley \& Sons, Inc., New York, N. Y., 1931). Methods of Chemical Analyses of Metals, (American Society for Testing Materials, 1936).

L. Brandt, Chem.-Ztg. 37, 1445, 1496 (1913).

S. B. Evans, Analyst $5 \%$. 492 (1932).

5 E. I. Fogel'son and N. V. Kalmuikova, Zavodskaya Lab. 5, 584 (1936).

${ }^{6}$ C. W. Anderson, Ind. Eng. Chem., Anal. Ed. 9, 569 (1937). 
For the determination of small amounts of arsenic in biological material, Morris and Calvery ${ }^{7}$ recommend a modification of Denigès' method, ${ }^{8}$ whereby a blue complex arsenic-molybdenum compound is formed. In the method to be described, the formation of this blue color is the basis for the determination of arsenic, which has previously been removed from interfering elements by distillation as arsenic trichloride. Antimony, which might distill in part under certain conditions, does not interfere.

The transmittancy of the colored solution is measured with a photoelectric colorimeter (or comparator). The quantity of arsenic is read from a standard curve drawn from data obtained by treating known amounts of arsenic in the same manner as is described for the unknown. The method has been applied to many types of ferrous and nonferrous alloys. It is more rapid than the usual macromethods and is especially useful with materials of very low arsenic content, such as pig lead.

\section{APPARATUS}

The Scherrer all-glass distilling apparatus, ${ }^{9}$ shown in figure 1 , was used to distill the arsenic trichloride. $C$ is a 200-ml distilling flask, the neck of which is $2.5 \mathrm{~cm}$ in diameter. It is provided with an exit tube, a thermometer well, and an inlet tube for conveying the acids and carbon dioxide to the distilling flask. Both the thermometer well and the inlet tube reach within $3 \mathrm{~mm}$ of the bottom of the flask. The distance between the

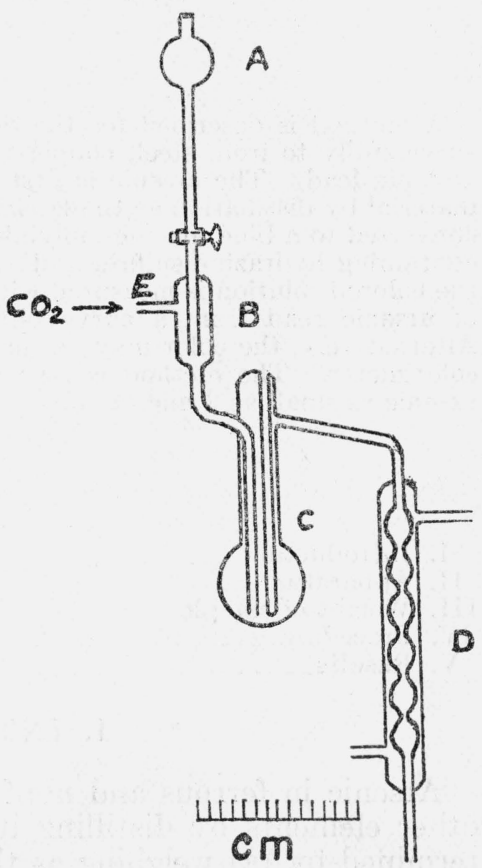

Figure 1.-Distilling apparatus. bottom of the flask and the exit tube leading to the condenser is $17 \mathrm{~cm}$.

The apparatus is clamped to a ring stand. $C$ rests on an asbestos board (about 18 by $18 \mathrm{~cm}$ ) having a round hole $4.5 \mathrm{~cm}$ in diameter.

The photoelectric colorimeter was constructed according to the design of Brice ${ }^{10}$ and consists of a balanced circuit using barrier-layer type photoelectric cells. The cylindrical absorption cells are $18 \mathrm{~mm}$ in internal diameter with the distance between the faces $2 \mathrm{~cm}$.

Examination of the colored solution with a hand spectroscope showed absorption in the red, and for this reason a Jena $\mathrm{OG}_{2}$ filter which transmits from $550 \mathrm{~m} \mu$ through the red was used.

A visual colorimeter, such as the Duboscq type, may also be used for determining the amount of arsenic by matching against solutions containing known amounts of arsenic.

\footnotetext{
7 H. J. Morris and H. O. Calvery, Ind. Eng. Chem., Anal. Ed. 9, 447 (1937).

8 G. Denigès, Pregl Festschrift, p. 27 (Mikrochemie, 1929).

- John A. Scherrer, J. Research NBS 16, 253 (1936) RP871; 21, 95 (1938) RP1116.

10 B. A. Brice, Rev. Sci. Instr. 8, 279 (1937). Also private communications.
} 


\section{WEIGHT OF SAMPLE}

Nonferrous alloys, particularly bearing metals, are prone to segregate, as is shown by the variation in results of macroanalyses of journal bearing:s. ${ }^{11}$ The composition of the large-sized particles of many alloys often differs from that of the small ones, and it is usually inconvenient or impossible to decrease the size of all the particles to the point where it becomes certain that a small sample (say less than $10 \mathrm{mg}$ ) is truly representative of the material. Experiments with samples of brass and bronze, as prepared for macroanalyses, have shown that there is a sufficient difference in composition of the chips to cause serious error if the analysis is made on a 5-to $10-\mathrm{mg}$ sample ( 4 to 5 chips), but when $100-\mathrm{mg}$ samples are taken, no such errors are encountered.

A 100-mg sample is therefore recommended as the minimum for materials in the form of small chips, ${ }^{12}$ unless tests have shown that there is no segregation, or the amount of sample is limited. For convenient comparison in the cells and instrument used, the sample should contain at least 2 micrograms of arsenic. A 100-mg sample of commercial steel, with arsenic contents ranging from 0.005 to 0.02 percent, fulfills this condition. The same weight of sample can be used for cast irons. However, with high-arsenic irons (arsenic $>0.03$ percent) it is necessary to dilute the colored solution, as described later.

If the arsenic content is such that $100 \mathrm{mg}$ of material does not give sufficient arsenic, the weight of the sample may be increased. For example, with lead of high purity (arsenic about 0.0005 percent) a $5-\mathrm{g}$ sample is required in order to obtain the optimum amount of arsenic.

\section{PROCEDURE}

Carbon steel.-Place a $0.1-\mathrm{g}$ sample in a $50-\mathrm{ml}$ beaker, dissolve the steel in $10 \mathrm{ml}$ of diluted nitric acid $(1+1)$, and evaporate the solution to dryness on a hot plate at a temperature not exceeding $130^{\circ} \mathrm{C}$. Cool, add $5 \mathrm{ml}$ of hydrochloric acid ( $\mathrm{sp}$ gr 1.18), and transfer the solution to the distilling apparatus (fig. 1) with the aid of a $10-\mathrm{ml}$ portion of hydrochloric acid. Add $2 \mathrm{ml}$ of hydrobromic acid. Mix $0.3 \mathrm{~g}$ of hydrazine sulfate with $10 \mathrm{ml}$ of hydrochloric acid ( $\mathrm{sp} \mathrm{gr} 1.18$ ), start the current of carbon dioxide and transfer the mixture to the distilling apparatus. Insert a thermometer in the well of the distilling flask and provide a receiver (150-ml tall-form beaker) containing $10 \mathrm{ml}$ of water into which the end of the condenser dips. Pass a stream of carbon dioxide through the apparatus at the rate of two or three bubbles per second, and boil the solution gently until the temperature reaches $111^{\circ} \mathrm{C}$. This requires approximately 15 minutes; the flask will contain about $10 \mathrm{ml}$ of solution at this stage. Without interrupting the stream of carbon dioxide or the heating, remove the receiver and rinse the end of the condenser with distilled water. Add $10 \mathrm{ml}$ of nitric acid (sp gr 1.42) to the distillate, place the beaker on a steam bath, and evaporate the solution to dryness. Heat the beaker and contents in an oven at $130^{\circ} \mathrm{C}$ for $1 / 2$ to 1 hour to remove all traces of nitric acid. Add $10 \mathrm{ml}$ of hydrazine sulfate-molybdenum solution ${ }^{13}$ for each 30

11 J. A. Scherrer and G. E. F. Lundell, BS J. Research 5, 891 (1930) RP237.

12 Particle size between Nos. 18 and 40 sieves, U. S. Standard.

13 The hydrazine sulfate-molybdenum solution is prepared as follows: Dissolve $1 \mathrm{~g}$ of ammonium molybdate in $100 \mathrm{ml}$ of $5 \mathrm{~N}$ sulfuric acid. Dissolve $0.15 \mathrm{~g}$ of hydrazine sulfate in $100 \mathrm{ml}$ of water. Dilute $10 \mathrm{ml}$ of the molybdate solution to $90 \mathrm{ml}$ with water, add $1 \mathrm{ml}$ of the hydrazine sulfate solution, and dilute with water to $100 \mathrm{ml}$. 
micrograms of arsenic, and heat the solution on a steam bath for 10 to 15 minutes. Cool, and dilute with hydrazine sulfate-molybdenum solution so that the solution contains no more than 3.0 micrograms of arsenic per milliliter. ${ }^{14}$ This is done conveniently in $10-$ to $250-\mathrm{ml}$ volumetric flasks. Measure the transmittancy of the solution with a photoelectric colorimeter, using the hydrazine sulfate-molybdenum solution in the comparison cell. Read the amount of arsenic from a standard curve which has been drawn from data obtained by treating known amounts of arsenic by the same procedure as is described for the unknown, and correct the result for a blank carried through the

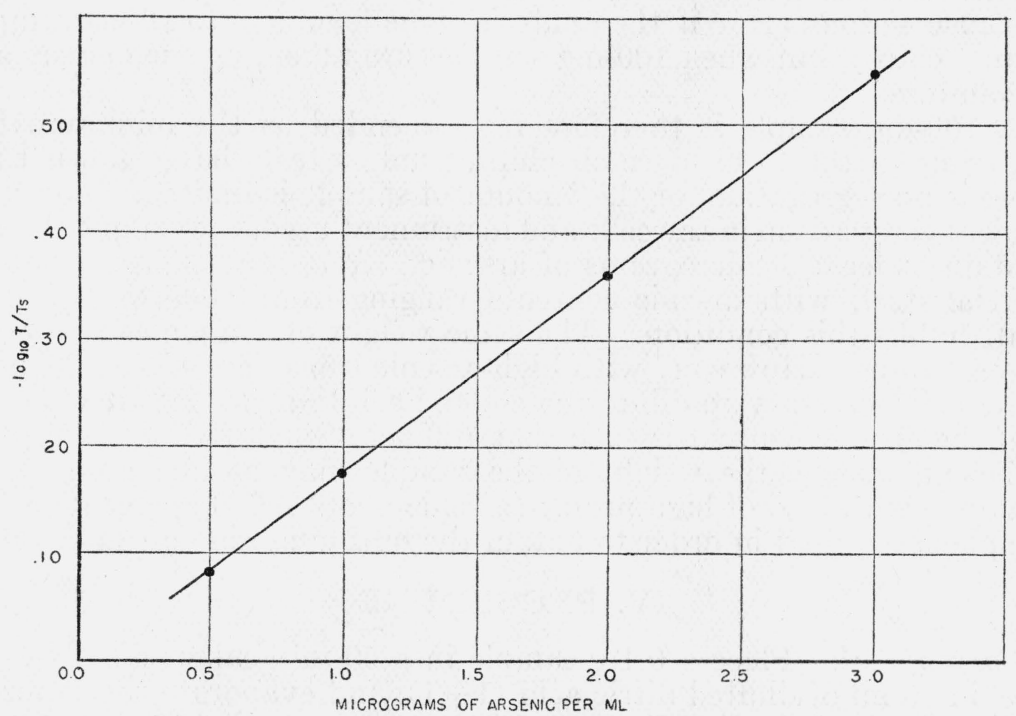

FIGURE 2.-Curve showing conformance to Beer's Law.

$T=$ Transmittancy of solution containing arsenic.

$T_{\bullet}=$ Transmittancy of blank hydrazine-sulfate-molybdate solution.

entire procedure. ${ }^{15}$ The standard curve is constructed by plotting micrograms of arsenic with respect to transmittancy.

The transmittancy measurements of solutions containing from 0.5 to 3.0 micrograms of arsenic per milliliter are reproducible to about 0.1 -percent transmittancy.

Experiments showed that the transmittancy of the solutions containing the arsenic-molybdenum compound did not change over a period of 24 hours. Figure 2 indicates that the colored solutions obey Beer's law in the region from 0.5 to 3.0 micrograms of arsenic per milliliter.

If a photoelectric colorimeter is not available, use a visual colorimeter to compare the color with that obtained from known amounts of arsenic. A Jena $\mathrm{OG}_{2}$ filter over the eyepiece of the colorimeter facilitates matching.

14 If the approximate amount of arsenic is unknown, $10 \mathrm{ml}$ of hydrazine sulfate-molybdenum solution is added, the solution is heated, cooled, and the transmittancy measured as directed. If the arsenic content exceeds 3 micrograms per milliliter, $15 \mathrm{ml}$ more of the reagent is added, and the solution is again beated, cooled, and the transmittancy measured. This operation is repeated until the arsenic content does not exceed 3 micrograms per milliliter.

1s With the reagents used, the blank ranged from 0 to 0.0002 percent of arsenic on the basis of a 100 -mg sample. 
High-chromium steel.-Dissolve a $0.1-\mathrm{g}$ sample in $10 \mathrm{ml}$ of a mixture of equal parts of nitric and hydrochloric acids. Evaporate to dryness and proceed as with carbon steel.

Cast iron.-Proceed as with carbon steel.

Ferromanganese.-Proceed as with carbon steel.

Brass, bronze, bearing metals.-Dissolve a $0.1-\mathrm{g}$ sample in $5 \mathrm{ml}$ of nitric acid (sp gr 1.42). Cool, add $8 \mathrm{ml}$ of diluted sulfuric acid $(1+1)$, and evaporate the solution to fumes of sulfuric acid. Cool, and add $5 \mathrm{ml}$ of water. Transfer to the distilling apparatus, and complete the determination as in carbon steel.

Pig lead.-Transfer a $5-\mathrm{g}$ sample to a $400-\mathrm{ml}$ beaker, add $100 \mathrm{ml}$ of diluted nitric acid $(1+3)$, and heat on a steambath. When solution is complete, cool, add $15 \mathrm{ml}$ of sulfuric acid (sp gr 1.84), and evaporate to fumes of sulfuric acid. Cool, add $20 \mathrm{ml}$ of water, and transfer to the distilling apparatus with $50 \mathrm{ml}$ of hydrochloric acid (sp gr 1.18). Add $10 \mathrm{ml}$ of hydrobromic acid. Then add $1 \mathrm{~g}$ of hydrazine sulfate to the distilling apparatus with an additional $50-\mathrm{ml}$ portion of hydrochloric acid (sp gr 1.18). Distill as with carbon steel, catching the distillate in $10 \mathrm{ml}$ of water contained in a $250-\mathrm{ml}$ beaker. Distill until approximately $90 \mathrm{ml}$ of distillate has passed over. Add $30 \mathrm{ml}$ of nitric acid (sp gr 1.42) to the distillate, evaporate to dryness on the steambath, and complete the determination as in carbon steel.

\section{RESULTS}

Table 1 shows the results obtained on some National Bureau of Standards Standard Samples of ferrous and nonferrous alloys and on two samples of pig lead prepared by the American Society for Testing Materials for cooperative analysis.

TABLE 1.-Results obtained for arsenic in some ferrous and nonferrous alloys

\begin{tabular}{|c|c|c|c|c|c|}
\hline \multicolumn{2}{|c|}{ Arsenic } & \multirow{2}{*}{ Material } & \multicolumn{2}{|c|}{ Arsenic } & \multirow{2}{*}{ Material } \\
\hline Present : & Found & & Present & Found & \\
\hline $\begin{array}{r}\text { Percent } \\
0.009\end{array}$ & $\left\{\begin{array}{r}\text { Percent } \\
0.008 \\
.009 \\
.009\end{array}\right.$ & $\begin{array}{l}\text { A. O. H. steel, NBS Standard } \\
\text { Sample } 34 a .\end{array}$ & $\begin{array}{r}\text { Percent } \\
0.031\end{array}$ & $\left\{\begin{array}{r}\text { Percent } \\
.023 \\
.026 \\
\square .025\end{array}\right.$ & $\begin{array}{l}\text { Tin-base bearing metal, NBS } \\
\text { Standard Sample 54a. }\end{array}$ \\
\hline .011 & $\begin{array}{l}.008 \\
.009\end{array}$ & $\left\{\begin{array}{l}\text { Stainless steel (13 percent, } \\
\text { chromium), NBS Standard } \\
\text { Sample 73. }\end{array}\right.$ & .069 & $\left\{\begin{array}{l}.059 \\
.061\end{array}\right.$ & $\begin{array}{l}\text { Lead-base bearing metal, } \\
\text { NBS Standard Sample 53a. }\end{array}$ \\
\hline .012 & $\begin{array}{l}.011 \\
.011 \\
.012\end{array}$ & $\left\{\begin{array}{l}\text { Ingot iron, NBS Standard } \\
\text { Sample } 55 .\end{array}\right.$ & .19 & $\left\{\begin{array}{l}.18 \\
0.23 \\
\text { d } 0010\end{array}\right.$ & $\begin{array}{l}\text { metal, NBS Standard } \\
\text { Sample } 63 \text {. }\end{array}$ \\
\hline .071 & $\begin{array}{l}.068 \\
.070 \\
.071\end{array}$ & $\left\{\begin{array}{l}\text { Cast iron, NBS Standard } \\
\text { Sample 7c. }\end{array}\right.$ & & $\begin{array}{r}.0015 \\
\text { d. } .0018\end{array}$ & Sample $37 \mathrm{~b}$. \\
\hline .26 & $\begin{array}{l}.24 \\
.25\end{array}$ & $\begin{array}{l}\text { Cast iron, NBS standard } \\
\text { Sample 6d. }\end{array}$ & & $\begin{array}{r}.0019 \\
d .00040\end{array}$ & \\
\hline .024 & .024 & $\begin{array}{l}\text { Ferromanganese, } \\
\text { Standard Sample } 68 .\end{array}$ & & $\left\{\begin{array}{l}.00046 \\
.004\end{array}\right.$ & Pig lead. \\
\hline
\end{tabular}

Values reported by determinations with conventional methods.

- By comparing color with Duboseq-type colorimeter.

- nalysis made on a 6-mg sample-value obtained indicative of nonhomogeneity of small samples.

d $V$ alues given to show the sensitivity and reproducibility of method.

Washington, November 1, 1939. 